\title{
Categories We Live By: The Construction of Sex, Gender, Race, \& Other Social Categories
}

\author{
ÁsTA \\ Oxford: Oxford University Press, 2018, 140 or. $^{1}$
}

Errefuxiatu, gizon, emakume edo trans moduko kategoria sozialek gure ekintzak mugatzen eta gure identitatea eta auto-ulermena zehazten dituzte. Baina, zer dira zehazki kategoria sozialak? Zein da beraien izaera? Nola sortzen dira? Zein mekanismoren bidez ahalbidetzen edota mugatzen dituzte zenbait portaera?

Liburu honetan, bai galdera horiei, bai antzeko beste batzuei, erantzuna ematen saiatu da Ásta ${ }^{2}$, kategoria sozialen teoria metafisiko berria aurkeztuz. Conferralism izena jarri dio teoria horri, eta, bertan, norbanakoaren propietate sozialak beste pertsonen uste eta praktiken ondorioz sortuak direla defendatzen du; norbanakoak dituen propietate sozialak besteek emanak (conferred) izan direla, hain zuzen.

Honako hau da ideiaren funtsa. Propietate soziala da norbanako bati emandako propietatea, oinarrizko propietate (base property) batzuen arabera. Ástak darabilen «oinarrizko propietate» termino honek erreferentzia egiten dio testuinguru jakin batean esanguratsua den propietate bati. Emandako propietatea, era berean, estatus soziala da, testuinguru horretan norbanakoaren portaeraren aukerek eta mugek osatzen dutena.

Kontuan izan, ikuspuntu honen arabera, zein garrantzitsua den emaileen (propietatea ematen dutenen) ebazpena oinarrizko propietate esanguratsuaren existentziari buruz; hau da, propietate jakin baten existentziaren ebazpena da garrantzitsua, ez propietate horren existentzia bera. Hori da Conferralism teoriaren ardatz nagusia eta, era berean, ezagunagoa den John Searleren Constitution Account for Social Properties (Searle 1997) teoriatik bereizten duena. Azken teoria horretan, propietate sozialek honako estruktura aski ezagun hau dute:

$X P$-tzat jotzen da $C$ testuinguruan (X counts as $\mathrm{P}$ in context $\mathrm{C}$ )

\footnotetext{
${ }^{1}$ Nire esker onak Alexander Martinez Iturriari eta GOGOAren zuzentzaile anonimoei, lan honen estilo-zuzenketekin laguntzeagatik. Edonola ere, nire ardurapean dago ager daitekeen edozein akats.

2 Islandiarrek ez dituzte abizenak erabiltzen, baizik eta patronimikoak. Horregatik, eta nahasteak saihesteko, 2017tik aurrera 'Ásta' sinatzen du egileak.
} 
Ikuspuntu honen arabera, zerbaitek P izateko eduki beharreko baldintzak zehaztu ondoren (edozein delarik ere erabilitako modua, izan uste kolektiboak, arauak, instituzioak...), baldintza horiek betetzen diren bakoitzean Pren kasua eratzen da, jendeak baldintza horien betetzearen ala ez betetzearen inguruan duen ebazpenaren araberakoa izan gabe. Haatik, Ástaren lanean, jendearen ebazpen epistemikoa da zerbait P-ren kasua den ala ez zehazten duena. Hurrengo kasuak argituko du ideia hori.

Futbol-partida baten testuinguruan, gerta daitezkeen gertaeren artean, golak dira garrantzitsuenetarikoak. Horiek gertatzen dira, laburbilduz, baloiak zenbait baldintza betetzen dituenean (alegia, bi ateetako lerroetako bat guztiz gurutzatzean). Orain, ikus dezagun zein modu ezberdinean interpretatzen duten gertaera hori aztertzen ari garen bi teoriek. Searleren interpretazioaren arabera, baloiak aurrez finkatutako baldintzak betetzeak gola eratzen du, epailearen erabakiarekin zerikusirik eduki gabe. Nahiz eta epailea oker egon eta baldintzak bete direla ez identifikatu, eta, ondorioz, gola markagailura igo ez, gola da. Ástaren interpretazioaren arabera, ordea, epailearen ebazpena da, hain zuzen ere, zerbait gola den ala ez zehazten duena. Beste modu batean esanda, epailearen ebazpena da propietatea eratzen duena. Ástaren aurka, Searleren teoriaren eta Conferralismaren artean ezberdintasun handirik ez dagoela argudia daiteke. Izan ere, Searleren onarpen kolektiboak (collective acceptance) propietate sozialak eratzen dituela defenda daiteke. Hau da, Searleren onarpen kolektiboak eta Ástaren talde esanguratsuaren ebazpenak antzeko rola jokatuko lukete. Ástak kontuan hartzen du kritika hau, baina Searleren interpretazioa okerra dela defendatzen du. Searleren onarpen koletiboak, argudiatzen du Ástak, zerbaitek X izateko baldintzak soilik zehazten ditu. Baldintza hauek betetzen diren ala ez, hori onarpen kolektibotik kanpo gelditzen da.

Ástak onartzen du erabili berri dudanaren moduko adibideek bi teorien arteko aldea ilustratzeko balio dutela; ez dagoela irakurketa zuzen ala okerrik, badagoela eztabaidarako esparrurik. Baina, goiko kasuan ez bezala, propietate sozialei dagokienez, ikuspuntu egokiena Conferralisma dela baieztatzen du.

Har dezagun kontuan, adibidez, emakume propietate soziala. Ástaren ideiaren arabera, inor ezin daiteke emakumea izan isolamenduan. Norbaitek bere buruan baino, besteek dituzten usteen eta jokabideen baitan dago inor emakume izatea. Emakume propietatea inorengan emana da (modu egokian, ala ez) talde jakin batek oinarrizko propietate bat, sozialki esanguratsua, atzeman duelako. Hala ere, eta hau da gakoa, ez da beharrezkoa oinarrizko propietate bat edukitzea propietate soziala emana izateko; soilik oinarrizko propietatea edukitzearen pertzepzioa ${ }^{3}$ da beharrezkoa Conferralism lan-eremuan

\footnotetext{
3 Nahiz eta Ástak hainbat alditan «pertzepzio» terminoa erabiltzen duen, argitu beharra dago ez duela zentzu faktikoan erabiltzen. Izan ere, gure pertzepzioetan oker egon gaitezkeela kontuan hartzea garrantzitsua da bere teoriarentzako.
} 
(antzeko moduan, baloiak ez du zertan atearen marra gainditu gola gol izateko, baldin eta epailearen ebazpenak gainditu duela badio).

Lehen atalean teoriaren ezaugarri orokorrak aurkeztu ondoren, bigarrenean, Ástak konstruktibismo sozialaren proiektuaz egiten du hausnarketa. Egileak bat egiten du proiektuaren ideia nagusiarekin eta bere «mozorroa kentzea» (debunking4) anbizioekin, baina zenbait ñabardurarekin. Ástaren arabera, mozorroa kentzeak edo agerian uzteak ez du zertan beti izan, askotan pentsatzen den bezala, naturala izateko pentsatutako propietatearen jatorri soziala agerian uztea. Mozorroa kentzeko proiektua, dio Ástak, ulertu beharko genuke testuinguru jakin batean zein propietate den operatibo agerian uzteko saiakeratzat. Ástak uste du argibide hori beharrezkoa dela, batzuetan, mozorroa kentzea dagoeneko sozialak direla jakina den propietateetan egin daitekeelako; kasu horietan, propietate operatiboa modu zehatzean identifikatzean datza, eta operatiboa beste propietate bat dela onartzera bideratzen duten uste okerrak agerian uztean. Ideia hau azaltzeko, egileak errefuxiatuen adibidea aurkezten du. Nahiz eta inork ez zukeen kategoria hori naturaltzat hartuko, argudio konbentzigarriz aldezten du Ástak zenbait mozorro-kentze interesgarri egin daitezkeela arduraz, bai kategoria honekin, bai antzeko beste hainbatekin.

Hirugarren atalean, Ástak sexuaren eta generoaren arteko bereizketa feminista tradizionalari egiten dio aurre; bereziki, generoa sexuaren esanahi sozialtzat definitzen duen ikuspegi post-beauvoirarrari. Hori egiteko, Judith Butlerren (1990) lan-ildoan sakonki murgiltzen da Ásta, eta harekin bat dator bi kategoria horien arteko dikotomia zalantzan jartzean. Zehazki, ideiaren funtsa honako hau da: generoa sexuaren esanahi soziala dela pentsatu beharrean, sexua generoaren eskema erregulatzaileen bidez gauzatua dela ikusi beharko genuke. Zentzu horretan, Butlerrekin ados dago Ásta esatean sexua ez dela soilik kategoria deskribatzailea, baizik eta, generoa bezalaxe, osagai arauemaile garrantzitsuak ere badituela.

Laugarren atalean, Ástak Conferralism teoria bai sexu, bai genero kategoriei aplikatzen die. Sexuaren kasuan, egileak Butlerren ikuspuntuari jarraipena ematen dio, nahiz eta, haren aurka, Ástak kontuan dauka badirela zenbait muga natural sexu batekoa izatearen inguruan. Zehazki, Ástak sinesten du sexua propietate emana dela, zeinean zenbait propietate fisiko atzemanak izan diren (modu egokian, ala ez), eta zeinean arau sozial eta kulturalek zehazten duten horietariko zein propietate fisiko diren esanguratsuak testuinguru bakoitzean. Generoari dagokionez, bestalde, Sally Haslangerrekin (2012) eta antzeko beste genero-teoriekin duen alde nagusia zera da: Ástaren arabera, genero kategoria (Ástaren ikuspuntuan, beste edozein kategoria

\footnotetext{
4 «Debunking» terminoa euskaratzen zaila da. Terminoak, propietate baten izaera soziala agerian uzteari egiten dio erreferentzia.
} 
sozial bezalaxe) testuinguruaren araberakoa da. Goian esan bezala, Conferralism teoriaren arabera, sozialki esanguratsuak diren oinarrizko propietateak eta, beraz, atzemanak izateko garrantzitsuak, guztiz alda daitezke testuingurutik testuingurura. Horrela bada, teoria honek esan nahi du askotan entzuten ditugun «zinez da emakumea» edota «benetako emakumea» gisako esaldiak, gehiago ez zehaztuz gero, zentzugabe bihurtzen direla. Inor ez da, besterik gabe, emakumea. Kategoria sozialak testuinguruan errotuak daude. Hortaz, norbait emakume izan daiteke testuinguru batzuetan, baina ez besteetan. Ástak aipatzen ez duen arren, Caster Semenya atleta hegoafrikarraren kasu polemikoa adibide gisa erabil daiteke, kategoria sozialak eta, bereziki, emakume kategoria testuinguruaren araberakoak direla irudikatzeko. 2018ko Nazioarteko Atletismo Federazioaren (IAAF) araudiaren arabera, Semenyak bezala, Sexuaren Garapenaren Diferentziaren (DSD) ondorioz, testosterona maila batezbestekoa baino altuagoa duten emakume kirolariek, ezin dute $400 \mathrm{~m}$ eta $1500 \mathrm{~m}$ arteko lasterketetan parte hartu, beren testosterona maila naturala botiken bitartez jaisten ez badute. IAAFaren arabera, testosterona maila bereziki baldintzagarria da distantzia hauetan. Kasuaren konplexutasunean sartu gabe, badirudi erakunde honen ondorioa dela kirolari hau emakumea dela 100 m-ko lasterketa batean, eta ez, ordea, $800 \mathrm{~m}$-ko beste batean.

Bosgarren atalean, beste zenbait kategoria soziali aplikatzen dio Ástak bere teoria; hala nola, arraza, erlijio edota ezintasunekin zerikusia dutenei. Arrazari dagokionez, egilea bat dator egun hedatua dagoen arrazaren definizio biologikoei egindako kritikarekin (Montagu 1964; Webster 1992), baina, aldi berean, arrazaren errealitatea azpimarratzen du; baliteke arrazak biologikoak ez izatea, baina errealak dira. Are gehiago, Ásta bat dator arrazak estatus sozialak direla dioen Haslangerren (2012) ideiarekin, baina ez dago ados pentsalari berak duen beste zenbait ikuspunturekin; esaterako, norbait arrazagatik kategorizatua izatea botere-estruktura hierarkikoan leku bat edukitzea dela dioenarekin. Ástak onartzen du, sarritan kasua hori izan daitekeen arren, Conferralism teorian egiturak testuinguruarekiko duen mendekotasuna dela-eta, posible dela norbait arrazagatik kategorizatua izatea, botere-estruktura hierarkikoekin zerikusirik zertan izan gabe. Zorritxarrez, egileak ez du aipatzen hierarkian oinarritzen ez den arraza-kategoriarik. Hori argigarria litzateke, eta lagunduko zukeen bere teoria Haslangerrena baino egokiagoa dela defenditzen.

Puntu horretaraino, liburua, batez ere, propietateak emanak izateko gaitasunaren fenomenoaz ari da. Hau da, propietate sozialak sortu eta mantentzen dituzten mekanismoez. Azken bi ataletan, haatik, egileak aztertzen du ea zenbat, eta zein modutan, eragiten dion emate honek kategorizatua izaten ari den gizabanakoari, eta haren auto-identifikazioari. Azken atala, hortaz, identitate sozialaren sorkuntza artikulatzeko ahalegina da, Ástaren kategoria sozialen teoria metafisiko orokorraren barnean lekua duena. 
Ástak identitate sozialaren teoria lantzeko duen modua da identitate sozialaren edozein teoriak eduki beharreko mugak zehaztea. Denak aipatu ezin ditzakedan arren, badira gogora ekartzeko moduko bi. Ástaren arabera, identitate sozialaren teoria batek eduki beharrekoa da, beste zenbait gauzaren artean, zentzua ematea pasatzearen (passing) fenomenoari (Mallon 2004) eta zentzua ematea identitate intersekzionalei. Lehenengoari dagokionez, konstruktibista sozial gehienek aurre egin beharreko arazoa da. Zailtasuna, pasatzearen fenomenoari zentzua ematea da. Hau da, badirudi bereizketa behar dugula, norbait $\mathrm{K}$ kategoriako partaide izatearen eta, besterik gabe, norbait $\mathrm{K}$ kategoriako partaidetzat jotzearen artean (adibidez, norbait mozorrotzen denean). Arazoa zera da, Conferralism teoriarentzat talde esanguratsuak norbait K-ko partaidetzat jotzea da, hain zuzen, K-ko partaide egiten gaituena. Zaila dirudi, beraz, ezberdintzea $\mathrm{K}$ izatea eta «K-tzat jotzea». Ageriko arazo horren inguruan, Ástak dio ez dagoela gertatzen denaren deskribapen zehatzik. K-tzat hartzearen eta $\mathrm{K}$ izatearen arteko bereizketan arreta ipini beharrean, Ástak dio, besterik gabe, passing hori gertatzen denean, Conferralism teoriaren funtsa diren oinarrizko propietate esanguratsuen presentziaren identifikazioa dela okerra. Hau da, passing hori gertatzen denean, kategoria eman egiten da, nahiz eta ebazpen okerraren emaitza izan, zenbait oinarrizko propietate bazirela pentsatzean, berez ez zeudenean. Gogoratu, gainera, Ástarentzat «zinez da emakumea» edota «benetako emakumea» bezalako esaldiak zentzugabeak direla, testuingururik ezean. Kategoria sozialak testuinguruan daude erroturik.

Bigarren mugari dagokionez, konstruktibista sozialek landu beharreko arazoetako bat gizabanakoaren identitate soziala ulertua izateko beharrezko dimentsioak zehaztea da. Alde batetik, kategoriak isolaturik analizatzeak gizabanako intersekzionalen esperientzia alde batera uzteko arriskua du. Hau da, hainbat kategoria zaurgarrietako partaide direnen diskriminazio berezia kontuan ez hartzeko arriskua dago. Adibidez, emakume beltz baten esperientziak ez dira soilik bi ezaugarri horietatik eratorritakoen gehiketa, baizik eta diskriminazio mota berri bat. Aldi berean, imajina daitekeen edozein kategoria kontuan edukiz gero, ezinezkoa da orokortze esanguratsu bat lortzea. Gizabanako bakoitzarentzat, hein batean, esklusiboa litzateke. Beste behin, conferralist esparruak duen testuinguruekiko mendekotasun bortitza dator erreskatean. Ástak dio identitate intersekzional horien inguruko kezkak desagertu beharko liratekeela testuinguru bakoitzean nabarmentzen den oinarrizko propietatea testuinguruak berak determinatzen duela ulertzean. Ez ditugu zertan gizabanako baten dimentsio guztiak kontuan eduki bere identitateari zentzua emateko; soilik testuinguruan esanguratsuak direnak inporta zaizkigu guri. Bada, gizabanako jakin baten portaera mugatua egon daiteke beltza delako, beste batena emakumea delako, eta, are gehiago, beste batena emakume beltza delako. 
Liburuak hasieran galdera argia dauka jomugan: zer da kategoria soziala? Erantzunak guztiz konbentzitu ala ez, ezin ukatu egilea bete-betean sartzen dela galderan, eta modu zuzen eta originalean, gainera. Conferralism teoria kategoria sozialen izaera metafisikoari zentzua emateko modu dotorea da, bai eta kategoria horien eta jendearen izaera eta usteen arteko dependentzia-erlazioa ulertzeko modua ere. Jakin-nahiarekin utz zaitzake, alabaina, ea nola aplika daitekeen lan esparru hori kategoriak ez diren beste fenomeno sozialetan, hala nola instituzioetan edota legeetan. Edozein kasutan, ezin Ástari leporatu zuriune hori, liburuaren hasieratik hori argi eta garbi utzi baitu. Laburbilduz, metafisika sozialean interesatua dagoen edonorentzat oso irakurketa gomendagarria da eta, batez ere, kategoria sozialen metafisikan lanean dabilenarentzat.

\section{Erreferentziak}

ButLer, Judith (1990), Gender Trouble: Feminisim and the Subversion of Identity. New York: Routledge.

Haslanger, Sally (2012), Resisting Reality: Social Construction and Social Critique. Oxford: Oxford University Press.

Mallon, Ron (2004), «Passing, Traveling, and Reality: Social Construction and the Metaphysics of Race». Noûs 38 (4): 644-673.

Montagu, Ashley (1964), Man's Most Dangerous Myth: The Fallacy of Race. Cleveland: World Publishing Company.

Searle, John (1997), The Construction of Social Reality. New York: Free Press.

WeBSTER, Yehudi (1992), The Racialization of America. New York: St. Martin's Press.

Iñigo Valero

Universitat de Barcelona 